\title{
Epidemiological profile of people affected by tuberculosis in Campina Grande - PB, between 2014 and 2018
}

\author{
Perfil epidemiológico de acometidos por tuberculose em Campina Grande - PB, entre \\ os anos de 2014 a 2018
}

\begin{abstract}
Francisco Patricio de Andrade Júnior ${ }^{1 *}$, Januse Míllia Dantas de Araújo ${ }^{2}$, Laísa Vilar Cordeiro ${ }^{1}$, Egberto Santos Carmo르. Vanessa Santos de Arruda Barbosa², Edeltrudes de Oliveira Lima ${ }^{1}$

${ }^{1}$ Postgraduate Program in Natural and Bioactive Synthetic Products, Federal University of Paraiba, Health Sciences Center, João Pessoa, PB; ${ }^{2}$ Federal University of Campina Grande, PB, Education and Health Center, Cuité,
\end{abstract} $P B$

\begin{abstract}
Introduction: tuberculosis is a bacteriosis caused by the etiological agent Mycobacterium tuberculosis, which initially affects the lungs, however it can become extrapulmonary. Although this infection is an important public health problem in Brazil, epidemiological studies on this disease are scarce. Objective: thus, the present study aimed to elucidate the epidemiological profile of people affected by tuberculosis in Campina Grande - PB, between the years 2014 to 2018. Methodology: this is an epidemiological, retrospective, analytical and documentary study, in which data were collected from the Department of Informatics of the "Sistema Único de Saúde". Results: Between 2014 and 2018, 795 cases of tuberculosis were reported in Campina Grande-PB, with 2018 having the highest number of cases (24.6\%). The epidemiological profile of those affected was predominantly male, aged 20 to 39 years, with low schooling, mixed race and residents of the urban area. When associating sex with immunosuppressive factors, a statistically significant association was observed between, HIV, the state of acquired immunodeficiency syndrome (AIDS) and alcoholism ( $p$ <0.05). Conclusion: in this way, the data of this research can guide the development of indicators and public policies for the most susceptible population.
\end{abstract}

Keywords: Mycobacterium. Tuberculosis. Epidemiology.

\begin{abstract}
Resumo
Introdução: a tuberculose é uma bacteriose causada pelo agente etiológico Mycobacterium tuberculosis, que inicialmente acomete os pulmões, entretanto pode tornar-se extrapulmonar. Mesmo esta infecção tratando-se de um importante problema de saúde pública no Brasil, há grande escassez de estudos epidemiológicos referentes a essa doença. Objetivo: o presente estudo teve como objetivo elucidar o perfil epidemiológico de acometidos por tuberculose em Campina Grande, PB, entre os anos de 2014 a 2018. Metodologia: trata-se de um estudo epidemiológico, retrospectivo, analítico e documental, em que os dados foram coletados a partir do Departamento de Informática do Sistema Único de Saúde. Resultados: entre 2014 a 2018, foram notificados 795 casos de tuberculose em Campina Grande, PB, sendo que o ano de 2018 foi aquele com o maior número de casos - 24,6\%. O perfil epidemiológico de acometidos foi, predominantemente, de indivíduos do gênero masculino, com 20 a 39 anos de idade, baixa escolaridade, etnia parda e residentes da zona urbana. Ao associar o gênero com os fatores imunossupressores, observouse associação estatisticamente significativa entre $\mathrm{VIH}$, estado de SIDA e alcoolismo $(p<0,05)$. Conclusão: assim, os dados desta pesquisa podem nortear o desenvolvimento de indicadores e políticas públicas para a população mais susceptível.

Palavras-chave: Mycobacterium. Tuberculose. Epidemiologia.
\end{abstract}

\section{INTRODUCTION}

Tuberculosis is an infectious disease caused by the acid-alcohol resistant bacillus (AARB) Mycobacterium tuberculosis. This bacillus primarily affects the lungs, however, especially in immunosuppressed individuals, it can reach the bloodstream and affect various organs (extra-pulmonary form) such as kidneys, bones and blad$\operatorname{der}($ KIAZYK; BALL, 2017; ROSETTO et al., 2017).

Correspondente/Corresponding: *Francisco Patricio de Andrade Júnior - End: Programa de Pós-Graduação em Produtos Naturais e Sintéticos Bioativos. R. Tab. Stanislau Eloy, 41 - Conj. Pres. Castelo Branco III, João Pessoa - PB, 58050-585. - Tel: (84) 98135-7242 - E-mail: juniorfarmacia. ufcg@outlook.com
Transmission occurs from the release of droplets of saliva from individuals infected with the bacillus. However, for this bacterium to infect healthy individuals there is dependence on the time and continuity of exposure, in addition to the immune and nutritional status, in which it is estimated that 100 to 200 hours are required for a successful infection to occur (KOZAKEVICH; SILVA, 2015).

Once the bacillus is able to settle in the lower airways and survive the immune response, the onset of the disease occurs in about 12 months after the initial contact, with dry or productive cough, tiredness, weight loss and afternoon fever (NOGUEIRA et al., 2012; BRASIL, 2020).

The clinical suspicion begins when the possible person has a dry or productive cough, lasting more than 
three weeks and the diagnosis is made in the laboratory through sputum smear microscopy using Ziehl Neelsen stain (COSTA; SILVA; GONÇALVES, 2018).

The treatment is basically pharmacological, with rifampicin, isoniazid, pyrazinamide and ethambutol as components of the basic scheme currently used. In addition, the BCG (Bacillus Calmette-Guérin) vaccine presents itself as the main form of prevention available (BRASIL, 2020).

In Brazil, tuberculosis presents itself as a disease of compulsory notification, presenting about 70,000 new cases of every year, with approximately 4,500 deaths (BRASIL, 2020). Thus, it is important to develop new research in order to better understand the epidemiological reality of different populations and outline more effective strategies to combat this disease.

Based on this, the present study aimed to elucidate the epidemiological profile of people affected by tuberculosis in Campina Grande - PB between the years 2014 to 2018.

\section{METHODOLOGY}

\section{Study design}

This is an epidemiological, retrospective, analytical and documentary study, in which data were collected from the "Departamento de Informática do Sistema Único de Saúde" (DATASUS).

\section{Study Location}

The city of Campina Grande is located in the Northeast region of Brazil, more specifically, in the interior of the state of Paraiba. The estimated population for 2019 was 409,731 inhabitants, with 2.2 salaries for formal workers in 2017. Regarding health, in 2009 there were 112 establishments linked to Sistema Único de Saúde, with $84.1 \%$ of adequate sewage in 2010 (IBGE, 2020).

\section{Variables analyzed}

The variables, number of cases, year, sex, age group, ethnicity, education, area of residence and immunosuppressive factors were analyzed.

\section{Statistical analysis}

The Statistical Package for Social Sciences software (version 13.0) was used for statistical analysis, in which absolute and relative frequencies were calculated for all variables. However, an association was made between the variables sex and age group, as well as sex and immunosuppressive factors. In addition, the Chi-Square test of Independence was used, in which $p<0.05$ was considered statistically significant for the null hypothesis. In addition, adjusted residuals and odds ratios were calculated.

\section{RESULTS}

Between 2014 and 2018, 795 cases of tuberculosis were found in the population of Campina Grande-PB, as can be seen in the figure below (figure 1).

Figure 1-Percentage of tuberculosis cases confirmed in Campina Grande-PB between the years 2014 to 2018.

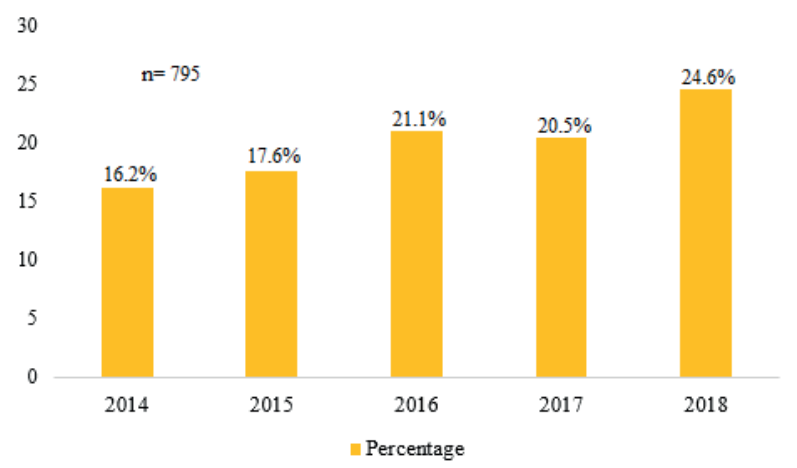

Source: Research data, 2020.

Table 1 shows the relationship between the age group and the sex of individuals affected by tuberculosis.

Table 1 - Association between age and sex of people affected by tuberculosis in Campina Grande - PB between the years 2014 to 2018

\begin{tabular}{|c|c|c|c|c|c|c|}
\hline \multirow[t]{2}{*}{ Age range } & \multicolumn{2}{|c|}{ Feminine } & \multicolumn{2}{|c|}{ Male } & \multicolumn{2}{|c|}{$\begin{array}{c}\text { Total by sex and } \\
\text { age group }\end{array}$} \\
\hline & $N$ & $\%$ & $N$ & $\%$ & $N$ & $\%$ \\
\hline$<1$ & 02 & 0.8 & 03 & 0.5 & 05 & 0.6 \\
\hline $1-4$ & 03 & 1.2 & 03 & 0.5 & 06 & 0.8 \\
\hline $5-9$ & 01 & 0.4 & 05 & 0.9 & 06 & 0.8 \\
\hline $10-14$ & 12 & 4.7 & 07 & 1.3 & 19 & 2.4 \\
\hline $15-19$ & 14 & 5.5 & 35 & 6.5 & 49 & 6.2 \\
\hline 20-39 & 98 & 38.8 & 248 & 45.8 & 346 & 43.5 \\
\hline $40-59$ & 70 & 27.7 & 162 & 29.9 & 232 & 29.2 \\
\hline $60-69$ & 34 & 13.4 & 45 & 8.3 & 79 & 9.9 \\
\hline $70-79$ & 13 & 5.1 & 28 & 5.2 & 41 & 5.1 \\
\hline$\geq 80$ & 06 & 2.4 & 06 & 1.1 & 12 & 1.5 \\
\hline Total & 253 & 100 & 542 & 100 & 795 & 100 \\
\hline
\end{tabular}

Source: Research data, 2020.

When assessing age 0-19, 20-59 and $\geq 60$ years by sex, an association was observed between the adult age group (20-59 years) with males and $\geq 60$ years with females ( $p=$ $0.023)$. Children and adolescents showed no association regarding the sex.

In figure 2, it is possible to observe the level of education of people affected by tuberculosis 
Figure 2 - Percentage of education level of individuals affected by tuberculosis in Campina Grande-PB between the years 2014 to 2018.

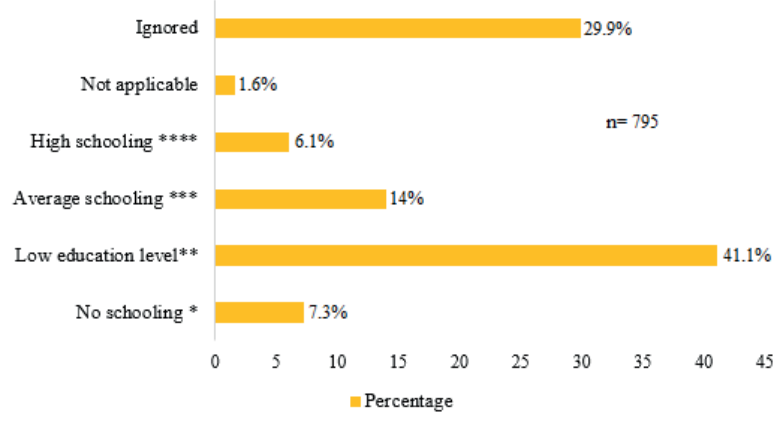

* Never studied; ** complete or incomplete elementary school; *** complete or incomplete high school; **** complete or incomplete higher education.

Source: Research data, 2020.

In table 2, it is possible to observe data regarding the ethnicity of the affected.

Table 2 - Absolute and relative frequency of ethnicity of individuals affected by tuberculosis in Campina Grande - PB between the years 2014 to 2018.

\begin{tabular}{lrr}
\hline \multirow{2}{*}{ Ethnicity } & \multicolumn{2}{c}{ Confirmed cases } \\
\cline { 2 - 3 } White & $\mathbf{N}$ & \% \\
\hline Black & 164 & 20.6 \\
Yellow & 91 & 11.4 \\
Mulatto & 04 & 0.5 \\
Indigenous & 498 & 62.7 \\
Ignored & 01 & 0.1 \\
\hline Total & 37 & 4.7 \\
\hline
\end{tabular}

Source: Research data, 2020.

Table 3 shows the place of residence of people affected by tuberculosis.

Table 3 - Area of occurrence and cases of people affected by tuberculosis in Campina Grande - PB between the years 2014 to 2018.

\begin{tabular}{lrc}
\hline Zone & N & \% \\
\hline Urban & 745 & 93.7 \\
Rural & 41 & 5.2 \\
Peri-urban & 01 & 0.1 \\
Ignored / Null & 08 & 1.0 \\
\hline Total & 795 & 100 \\
\hline
\end{tabular}

Source: Research data, 2020.

The development of tuberculosis is favored, mainly, in situations in which the individual has conditions that can trigger immunosuppression (table 4).
Table 4 - Association between sex and immunosuppressive factors of individuals affected by tuberculosis in Campina Grande - PB between the years 2014 to 2018.

\begin{tabular}{|c|c|c|c|c|c|c|c|}
\hline \multirow{2}{*}{$\begin{array}{l}\text { Immunosuppres- } \\
\text { sive factors } \\
\text { HIV test result }\end{array}$} & \multicolumn{2}{|c|}{ Male } & \multicolumn{2}{|c|}{ Female } & \multicolumn{2}{|c|}{ Total } & \multirow[t]{2}{*}{$\begin{array}{c}P \\
\text { OR }(\mathrm{Cl})\end{array}$} \\
\hline & $\mathrm{N}$ & $\%$ & $\mathrm{~N}$ & $\%$ & $\mathrm{~N}$ & $\%$ & \\
\hline Positive & $60+$ & 17,4 & 16 & 10,4 & 76 & 15,3 & 0,043 \\
\hline Negative & 284 & 82,6 & 138 & 89,6 & 422 & 84,7 & $1,822(1012-3,280)$ \\
\hline Total & 344 & 100 & 154 & 100 & 498 & 100 & \\
\hline \multicolumn{8}{|l|}{ AIDS status } \\
\hline Yes & $56+$ & 13,3 & 16 & 7,7 & 72 & 11,4 & 0,037 \\
\hline No & 366 & 86,7 & 193 & 92,3 & 559 & 88,6 & $1,846(1,031-3,304)$ \\
\hline Total & 253 & 100 & 209 & 100 & 631 & 100 & \\
\hline \multicolumn{8}{|l|}{ Alcoholism } \\
\hline Yes & 120 & $27,9+$ & 16 & 7,9 & 136 & 21,5 & $<0,001$ \\
\hline No & 310 & 72,1 & 187 & 92,1 & 497 & 78,5 & $4,524(2,604-7,860)$ \\
\hline Total & 430 & 100 & 203 & 100 & 633 & 100 & \\
\hline
\end{tabular}

$p$-Chi-Square Test of Independence;

OR-odds ratio;

$\mathrm{Cl}$-Confidence interval;

+ adjusted standardized $\geq 1,96$;

Source: Research data, 2020.

\section{DISCUSSION}

In view of the data analysis, it was observed that there was a significant increase in the number of tuberculosis cases over the years. The year 2018 stood out for the highest number of notifications, representing $24.6 \%$ of the total number, followed by the year 2016 with 21.1\% and 2017 with $20.5 \%$ (figure 1).

The increase in the number of reported cases over the years can be justified by the implementation of the "Programa Nacional de Controle da Tuberculose (PCNT)", which has, among its objectives, the early diagnosis of the disease (BRASIL, 2017). However, the abandonment of pharmacotherapy, the lack of information and the refusal to seek health services, may also be associated.

Regarding the sex of the affected individuals, there was a male predominance, with $68.2 \%$. The analyzed data are similar to those reported in a study developed in the city of Natal-RN, in which a greater involvement of tuberculosis was evidenced in male individuals, representing $69.5 \%$ of those infected (ANDRADE JÚNIOR et al., 2019). The data presented also corroborate with a study carried out in Caxias-MA between the period 2006 to 2016 in which the results showed that $65.6 \%$ of the individuals affected by tuberculosis were male (MACEDO et al., 2017). In addition, the data referring to sex and age group were in agreement with the results of a study carried out in the city of Rio Branco-AC, in which 700 cases of tuberculosis with greater involvement in male individuals were found (75.9\%), aged 20 -39 years (59.4\%) (RODRIGUES et al., 2019).

The predominance of male individuals in adult age group this disease has been related to sociocultural factors explained by the high consumption of alcohol and / 
or tobacco, which can be associated with the impairment of the immune system and nutritional status, increasing the susceptibility to contract tuberculosis. Other aspects that can influence this predominance are linked to the more intense exposure of male individuals to places with higher risks of contagion and transmission of tuberculosis, in addition to the fact that women tend to seek health services more frequently when compared to men, hindering the early diagnosis of the disease in this group (SILVA et al., 2018).

Another factor that can contribute to the emergence of tuberculosis is the educational level of the people affected (figura 2).

It was evidenced that, among those affected, the most prevalent were individuals with less education, similar to a study carried out in Natal-RN (ANDRADE JÚNIOR et al., 2019). The predominance of low schooling is presented as important information, as individuals with less years of study have difficulties in accessing information and knowledge about prophylactic and self-care measures.

In addition, it has been shown that individuals with few years of study are more likely to abandon anti-tuberculosis pharmacotherapy (FURLAR; OLIVEIRA; MARCON, 2012), contributing to increased mortality, greater dispersion of pathogens, contamination and infection of other individuals and resistance phenomena.

As for the ethnicity variable, it was found that the self-declared mulatto population represented the majority of reported cases. The data presented is similar to a study carried out in 2018, in the city of Açailândia-MA in which $89 \%$ of individuals with tuberculosis were mulattos (MORAES et al., 2017).

The greater involvement of tuberculosis in mulattos individuals can be explained by the predominance of this ethnicity in Campina Grande-PB (IBGE, 2020). However, its high prevalence is worrisome, since social stigma can make these individuals avoid seeking health services, causing problems in continuing with pharmacological treatment and increasing the chances of total abdication from therapy, when compared to individuals whites (SOUZA; SILVA; MEIRELLES, 2010).

Regarding the number of tuberculosis cases by area of occurrence, it was found that the largest number of cases occurred in the urban area, similar to studies carried out in Natal-RN and Piripiri-PI (ANDRADE JÚNIOR et al., 2019; MASCARENHAS; ARAÚJO; GOMES, 2005). One of the reasons that may justify the higher occurrence of cases in urban areas is the greater exposure of those affected to agglomerations (BRASIL, 2020), facilitating the bacillus to be passed between individuals.

Within a total of 498 tuberculosis cases, $15.3 \%$ had HIV co-infection, of which $78.9 \%$ were male. HIV co-infection was positively associated with males, with an occurrence 1.8 times higher in this sex $(p=0.043) .297$ cases had their HIV diagnosis ignored or inconclusive. $11.4 \%$ of the 631 cases had AIDS, $77.8 \%$ of whom were male. AIDS was positively associated with males, occurring 1.8 times higher in this sex $(p=0.037) .164$ cases had the AIDS condition ignored. $21.5 \%$ of the 633 tuberculosis cases had alcoholism. Of these, $88.2 \%$ were men. This condition was shown to be associated with males, occurring 4.5 times higher in this sex $(p<0.001)$. (Table 4). 162 cases were recorded for the absence of ignored alcoholism. 99\% of the 795 cases of tuberculosis were ignored.

These results differ from a study carried out in Natal-RN, in which only $0.8 \%(n=14)$ of women and $0.5 \%(n=18)$ of men studied were found to be reactive. (ANDRADE JÚNIOR et al., 2019). However, a worrying situation is that $36.2 \%$ of the studied population did not have an HIV test performed, which, in turn, precludes early diagnosis and, if reactive, the initiation of immediate pharmacological treatment with antiretrovirals, as it has been demonstrated that knowing the positive serology for HIV greatly increases the life expectancy of the person living with the virus, in addition to being able to prevent the appearance of co-morbidities, such as tuberculosis, pneumonia, toxoplasmosis, viral hepatitis and certain cancers. Furthermore, Pawlowski et al. (2012) showed that the presence of HIV can increase the development of active tuberculosis by up to 20 times, either through latent reactivation by $M$. tuberculosis or reinfection. Regarding the status of AIDS (Acquired Immunodeficiency Syndrome) and sex, a statistically significant association was observed $(p<0.05)$. Approximately $7.7 \%$ of women and $13.3 \%$ of men are in this clinical condition, with lower prevalence when compared to a study carried out in Natal-RN, where $11.3 \%(n=195)$ of women and $15.8 \%(n=817)$ of the men had AIDS (ANDRADE JÚNIOR et al., 2019).

The AIDS status is characterized laboratorially by lymphopenia, leading these individuals to immunodepletion and, therefore, facilitating the development of pathogens such as Koch's bacillus (PAWLOWSKI et al., 2012; CARVALHO; HAMER, 2016). In addition to this, it has been reported that the status of HIV / AIDS has contributed not only to the increase in active tuberculosis, but also to resistance phenomena (SINGH; MUNAWWAR, 2012; FERREIRA; SOUZA; MOTTA, 2019).

Thus, it is evident that HIV / AIDS associated with tuberculosis can hinder pharmacological and self-care treatment, promoting greater financial expenses to SUS and higher mortality, which reinforces the importance of early diagnosis and treatment for both infections.

Only $0.2 \%$ of male individuals were smokers. The low prevalence of smoking in this research was an important finding, since this practice contributes to difficulties in adhering to treatment, resistance phenomena and recurrences (NOVOTNY et al., 2017).

There was a statistically significant association between alcoholism and sex $(p<0,05)$, with a predominance for male individuals, with $27.9 \%$, while for females it was only $7.9 \%$. The use of alcohol by tuberculous individuals is associated with the interruption of pharmacotherapy, due to the appearance of hepatotoxicity (SILVA et al., 2018).

Thus, it is observed that the profile of people affected 
by tuberculosis should not be limited only to social and demographic characteristics, but also related to habits, cultural and pathological issues.

It is important to highlight in the present study that the high number of ignored data may indicate precarious data collection, becoming a major obstacle for epidemiological studies of this type (FURLAN, 2012). However, these data referring to ignored cases, can serve as an alert and instrument for the optimization of future records, by the local health authorities.

\section{CONCLUSIONS}

Between 2014 and 2018, 795 cases of tuberculosis were reported, with 2018 having the highest number of cases.

The epidemiological profile of those affected was predominantly male, aged 20 to 39 years old, with a statistically significant association between the adult age group (20-59 years) with the males and $\geq 60$ years with females, less educational level, mulatto ethnicity and residents of the urban area.

When associating sex with immunosuppressive factors, a greater predominance was observed between males and HIV, AIDS and alcoholism, as well as, statistically significant association.

Thus, the data present in this research may contribute to guide other epidemiological studies involving tuberculosis. In addition, it is expected to promote useful information for the creation of indicators and public policies for the most susceptible population.

\section{REFERENCES}

ANDRADE JÚNIOR, F. P. et al. Profile of tuberculosis patients in Natal-RN, Brazil, from 2010 to 2018: a documentary study. Scientia plena, [s.I.], v. 15, n. 10. p.1-9, 2019.

BRASIL. Ministério da Saúde. Programa Nacional de Controle da Tuberculose. 2016. Disponível em: http://portalarquivos.saude.gov. br/images/pdf/2017/fevereiro/21/Apresentacao-sobre-os-principais-indicadores-da-tuberculose.pdf. Acesso em: 05 mar. 2020.

BRASIL. Ministério da Saúde. Tuberculose: o que é, causas, sintomas, tratamento, diagnóstico e prevenção. 2020. Disponível em: http:// www.saude.gov.br/saude-de-a-z/tuberculose. Acesso em: 01 jan. 2020.

CARVALHO, R. C.; HAMER, E. R. Perfil de alterações no hemograma de pacientes HIV+. Rev. Bras. Anál. Clín., Rio de Janeiro, v. 49, n.1, p.5764, 2016.
COSTA, R. R.; SILVA, M. R.; GONÇALVES, I. C. Diagnóstico laboratorial da tuberculose: Revisão de literatura. Rev. Méd. Minas Gerais, Belo Horizonte, v. 28, n. 5, 2018.

FERREIRA, D. P.; SOUZA, F. A.; MOTTA, M. C. S. Prevalência da coinfecção HIV/TB em pacientes de um hospital de referência na cidade do Rio de Janeiro. Rev. Pesqui., Rio de Janeiro, v. 11, n. 2, p. 358-362, 2019.

FURLAN, M. C. R.; OLIVEIRA, S. P.; MARCON, S.S. Fatores associados ao abandono do tratamento de tuberculose no estado do Parana. Acta Paul. Enferm., São Paulo, v. 25, n.1, p.108-114, 2012.

INSTITUTO BRASILEIRO DE GEOGRAFIA E ESTATÍSTICA (IBGE). Campina Grande, 2020. Disponivel em: https://cidades.ibge.gov.br/brasil/pb/ campina-grande/panorama. Acesso em: 03 jan. 2020.

KIAZYK, S.; BALL, T. B. Tuberculosis (TB): Latent tuberculosis infection: An overview. Can. Commun. Dis. Rep., Ottawa, v. 43, n. 3-4, p.62, 2017.

KOZAKEVICH, G. V.; SILVA, R. M. Tuberculose: revisão de literatura. ACM Arq. Catarin. Med., Florianópolis, v. 44, n. 4, p. 34-47, 2015.

MACEDO, J. L. et al. Perfil epidemiológico da tuberculose em um Município do Maranhão. Reon Facema, Caixias, v. 3, n. 4, p. 699-705, 2017.

MASCARENHAS, M. D. M.; ARAÚJO, L. M.; GOMES, K. R. O. Epidemiological profile of tuberculosis among notified cases in the municipality of Piripiri, Piauí State, Brazil. Epidemiol. Serv. Saúde, Brasília, v. 14, $n$. 1, p. 7-14, 2005.

MORAES, M. F. V. et al. Perfil epidemiológico de Casos de tuberculose em hum minicípio Prioritário nenhum estado do Maranhão. Revista de Pesquisa em Saúde, São Luis, v. 18, n. 3, p. 147-150, 2017.

PAWLOWSKI, A. et al. Tuberculosis and HIV co-infection. Plos Pathog., San Francisco, v.8, n.2, 2012.

RODRIGUES, A. L. et al. Características e aspectos epidemiológicos dos casos de tuberculose em um município da amazônia legal. Rev. Remecs, São Paulo, v. 4, n.7, p.47-53, 2019.

ROSSETTO, M. et al. Comunicação para promoção da saúde: as campanhas publicitárias sobre tuberculose no Brasil. Rev. Enferm. UFSM, Santa Maria, v. 7, n. 1 p. 18-28, 2017.

SILVA, D. R. et al. Fatores de risco para tuberculose: diabetes, tabagismo, álcool e uso de outras drogas. J. Pneumol., Brasília, v. 44, n. 2, p. 145-152, 2018.

SINGH, S.; MUNAWWAR, A. Aids associeted tuberculosis: a catastrophic collision to evade the host immune system. Tuberculosis, Edinburgh, $v$. 92, n. 5, p. 384-387, 2012.

SOUZA, S.S.; SILVA, D.M.G.V.; MEIRELLES, B.H.S. Representações sociais da tuberculose. Acta Paul. Enferm., São Paulo, v. 23, n. 1, p. 23-28, 2010.

Submetido em: 29/06/2020

Aceito em: 06/04/2021 